\title{
Water Sprinkling of Log Decks to Reduce Emergence of Mountain Pine Beetle in Lodgepole Pine
}

by

\author{
L.H. McMullen ${ }^{1}$ and R.E. Betts ${ }^{1}$
}

\begin{abstract}
Water sprinkling of lodgepole pine logs infested by mountain pine beetle with soaker-hoses on the surface of log decks, reduced survival of pupae and young adults to $5 \%$ compared with $93 \%$ in control decks. The technique provides a useful alternative to other methods of reducing hazard from the insect to pine stands surrounding log storage areas.
\end{abstract}

\section{Résumé}

Un arrosage à l'eau, avec des tuyaux perforés, à la surface de dépôts de billes de pin tordu latifolié infestées par le dendroctone du pin ponderosa a réduit la survie des pupes et des jeunes adultes à $5 \%$, en comparaison de $93 \%$ dans les dépôts non arrosés. Contre cet insecte, cette technique remplace utilement d'autres méthodes de protection des peuplements de pin voisins des entrepôts de billes.

\section{Introduction}

The mountain pine beetle (Dendroctonus ponderosa Hopk.) is a serious pest of mature pines (Pinus spp.) in western Canada. In recent years, damage caused by this bark beetle has been especially severe in lodgepole pine ( $P$. contorta Dougl.) stands; e.g., in 1979 an estimated 7.7 million $\mathrm{m}^{3}$ were killed in British Columbia (Safranyik et al. 1981).

Logging of infested trees to remove the beetles from the stand is the major approach to reducing damage. When infested logs are stored at mill sites, or other storage areas, they represent a hazard to surrounding pine stands during the period when young beetles emerge (mid-July to September) and fly to attack healthy trees. Although utilization of infested logs before the flight period eliminates the hazard, such is not always possible. Debarking and destruction of the bark, or use of bark penetrating pesticides are expensive and, in the case of the latter, may be environmentally undesirable.

Water sprinkling has been successfully used to prevent attack by ambrosia beetles (Richmond and Nijholt 1972), as well as woodborers (Roff and Dobie 1968). McMullen and Betts (1981) demonstrated that intensive water sprinkling on individual bolts of infested lodgepole pine reduced emergence of mountain pine beetle by about $99 \%$ during and after 5.5 weeks of continuous treatment. This report describes a study of the effect of water sprinkling in log decks for reducing emergence of mountain pine beetle.

\section{Materials and methods}

Three log decks were constructed in late June, one (A) for a control (untreated) and ${ }_{t}^{+}$wo $(B$ and $C)$ for treatment at the

${ }^{1}$ Environment Canada, Canadian Forestry Service, Pacific Forest Research Centre, 506 West Burnside Road, Victoria, BC V8Z 1 M5.
Weldwood of Canada, Ltd. millsite, Williams Lake, British Columbia. The log decks were 4.5 to $5 \mathrm{~m}$ high; the control deck was approximately $5 \mathrm{~m}$ long and the two treatment decks were $11 \mathrm{~m}$ long exclusive of the supporting logs at both ends, and consisted of approximately 5 -m-long logs. To ensure infestation of logs to be sampled, lodgepole pine logs ( 25 to $50 \mathrm{~cm}$ diam) known to contain brood of mountain pine beetle (experimental logs) were arranged roughly in vertical columns of seven to nine logs, the columns being about 1 $\mathrm{m}$ apart within the decks. The control deck had three columns of experimental logs and the two treatment decks had eight columns (Fig. 1). The logs between the columns of experimental and supporting logs at either end of the decks were primarily lodgepole pine in deck $\mathrm{C}$ and western hemlock (Tsuga heterophylla (Raf.) Sarg.), (used because of its availability at the millsite and relative similarity to lodgepole pine of surface bark features), in decks A and B.

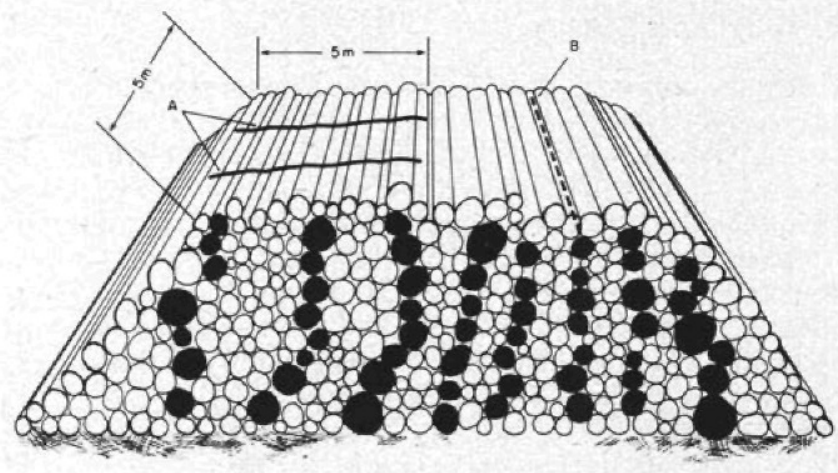

Figure 1. Diagrammatic representation of a log deck showing the distribution of experimental lodgepole pine logs infested by mountain pine beetle (solid ends) and soaker hoses on the surface of $(A)$ and within (B) the deck.

Two $1.3 \mathrm{~cm}$ diameter vinyl-foam soaker-hoses $5 \mathrm{~m}$ long were placed $2.5 \mathrm{~m}$ apart along the upper surface of decks $B$ and $C$ over the first three columns of infested logs. An additional $5 \mathrm{~m}$ soaker hose was inserted above the centre column of the five additional columns of infested logs but below the top logs in the deck to confine the spray (Fig. 1). This hose was meant to provide information on an alternative configuration of hoses within a deck. Water was supplied to the total $30 \mathrm{~m}$ length of soaker-hoses through a $2.5 \mathrm{~cm}$ hose at the rate of approximately $4.6 \mathrm{~m}^{3}$ per hour ${ }^{2}$. Sprinkling was started on July 8 , when the insect was primarily in the pupal and young adult stage and before flight had occurred, and was terminated on August 18, 41 days later, when most of the beetles would have emerged.

The decks were dismantled on August 19 and the experimental logs sampled August 19 to 24. Each log was divided into three equal sections (about $1.7 \mathrm{~m}$ each) and six $81 \mathrm{~cm}^{2}$ circular samples of bark (three from the top and

${ }^{2}$ Measured with a Trident water meter, Neptune Meter Co., N.Y. 
Table 1. The effect of water sprinkling on survival and emergence of mountain pine beetle in infested logs in decks, Williams Lake, 1981.

\begin{tabular}{|c|c|c|c|c|c|c|c|c|}
\hline \multirow{3}{*}{$\begin{array}{l}\text { Treatment } \\
\text { (sprinkling) }\end{array}$} & \multirow{3}{*}{$\begin{array}{l}\text { Wetting } \\
\text { Index }{ }^{1}\end{array}$} & \multicolumn{2}{|c|}{ Number of } & \multicolumn{4}{|c|}{ Numbers $/ \mathrm{m}^{2}$} & \multirow{3}{*}{$\begin{array}{c}\text { Estimated } \\
\text { beetle } \\
\text { survival }\end{array}$} \\
\hline & & \multirow[t]{2}{*}{ logs } & \multirow[t]{2}{*}{$\overline{\text { samples }}$} & \multirow{2}{*}{$\begin{array}{c}\text { Exit } \\
\text { holes }\end{array}$} & \multicolumn{2}{|c|}{ Young beetles } & \multirow{2}{*}{$\begin{array}{c}\text { Estimated } \\
\text { beetle } \\
\text { emergence }\end{array}$} & \\
\hline & & & & & living & dead & & \\
\hline Control & 0 & 27 & 475 & $462(17)^{2}$ & $16(4)$ & $60(8)$ & 756 & 92.8 \\
\hline Soaker-hose & 0 & 27 & 480 & $391(17)$ & $2(1)$ & $53(7)$ & 665 & 92.6 \\
\hline within deck & 1 & 7 & 126 & $244(31)$ & $18(6)$ & $227(39)$ & 437 & 66.7 \\
\hline & 2 & 15 & 279 & $162(17)$ & $11(3)$ & $430(34)$ & 231 & 36.0 \\
\hline & 3 & 25 & 432 & $33(5)$ & $6(2)$ & $495(27)$ & 38 & 7.3 \\
\hline $\begin{array}{l}\text { Soaker-hose on } \\
\text { deck surface }\end{array}$ & 3 & 49 & 853 & $26(4)$ & $5(2)$ & $739(24)$ & 31 & 4.6 \\
\hline
\end{tabular}

1 See text for explanation

${ }^{2}$ Number in ( ) = standard error

three from the bottom) were taken from each section. Damage to bark during sorting and deck construction activity occasionally made samples unusable. Numbers of emergence holes, dead and living pupae, and young unemerged adults were recorded for each sample. In addition, an index of the amount of wetting $(0=$ nil, $1=$ one quarter, $2=$ three quarters, 3 = complete) was estimated on the top and bottom surface of each $1.7 \mathrm{~m}$ section of log and averaged for the log. The number of exit holes and bark beetle progeny per sample were converted to number per $\mathrm{m}^{2}$. Since more than one beetle may emerge from a single exit hole when population density is high, the number of beetles that may have emerged from each sample was estimated by Reid's (1963) logarithmic relationship to number of emergence holes.

\section{Results and Discussion}

Results show that sprinkling with soaker hoses on the surface reduced emergence and, in fact, caused mortality of most of the young beetles (Table 1). Only about $5 \%$ of the beetles survived the sprinkling compared with $93 \%$ in the unsprinkled deck. Estimates of emerging beetles from the sprinkled logs is probably high because most of the few emergence holes were probably made by re-emerging parents before treatment. A similar number of emergence holes in the unsprinkled deck would also be attributable to re-emerging parents.

The effect of the single hose through the deck indicates the need for thorough soaking (Table 1). Approximately $36 \%$ of the beetles, in logs that were three-quarters wetted, survived. This level of survival is too high to be considered effective suppression in log storage areas.

The amount of water used in this study was considerable, about $4600 \mathrm{~L} / \mathrm{h}$, which amounts to approximately $6100 \mathrm{~L} / 100$ $\mathrm{m}^{2}$ of deck surface/hour assuming that two $5 \mathrm{~m}$ hoses covered $25 \mathrm{~m}^{2}$ of deck surface. However, we estimated that about $3000 \mathrm{~L} / \mathrm{hr}\left(4000 \mathrm{~L} / 100 \mathrm{~m}^{2}\right.$ deck surface/h) would have provided required coverage. The amount of water recommended by Roff and Dobie (1968) and Richmond and Nijholt (1972), although for a different purpose, was respectively, about .05 and .12 of the amount used in this study. It is unlikely that emergence of bark beetles can be reduced to safe levels with such a drastic reduction in water, since logs have to be thoroughly soaked.

Sprinkling of log decks with soaker-hoses on the surface of the decks prevented emergence, and eliminated the hazard to surrounding pine stands from beetles emerging from infested lodgepole pine logs. Although the practical use of this technique depends on water supply and the disposal of runoff, it does provide an alternative to other methods of reducing the hazard to pine stands surrounding log storage areas.

Based on the results of this study and that of McMullen and Betts (1981) the following two conditions should be met:

1) Sprinkle continuously at least one week before first emergence (emergence normally occurs about mid-July in central BC) and thereafter for five to six weeks.

2) Ensure that all logs are kept continuously wetted during the sprinkling period.

\section{Acknowledgments}

We especially thank Mr. A. Coombs, Mr. W. Box, and Mr. P. Voykin of Weldwood of Canada Ltd., Williams Lake, BC, for use of the millsite and for arrangements for moving the logs and supplying the water. We also thank the Protection Branch, British Columbia Ministry of Forests for their support.

\section{References}

McMullen, L.H. and R.E. Betts. 1981. Water sprinkling inhibits emergence of mountain pine beetle. Environment Canada Forestry Service Res. Notes 1: 10-11.

Richmond, H.A. and W.W. Nijholt. 1972. Water misting for log protection from ambrosia beetles in BC. Environment Canada Forestry Service, Pacific Forest Research Centre Rpt. BC P. $4-72,34 \mathrm{p}$.

Reid, R.W. 1963. Biology of mountain pine beetle, Dendroctonus monticolae Hopkins, in the East Kootenay Region of British Columbia. III Interaction between the beetle and its host with emphasis on brood mortality and survival. Can. Ent. 95: 225-238.

Roff, J.W. and J. Dobie. 1968. Water sprinklers check biologica deterioration in stored logs. British Columbia Lumberman 52(5): $60-63,70-71$.

Safranyik, L., G.A. Van Sickle and G.H. Manning. 1981. Position paper on mountain pine beetle problems with special reference to the Rocky Mountain Parks Region. Environ. Can. For. Serv. Pacific Forest Research Centre, March, 27 p. 